\title{
Review \\ Biomarkers to Detect Early-Stage Colorectal Cancer
}

\author{
Jacqueline I. Keenan * and Frank A. Frizelle
}

check for updates

Citation: Keenan, J.I.; Frizelle, F.A. Biomarkers to Detect Early-Stage

Colorectal Cancer. Biomedicines 2022, 10, 255. https://doi.org/10.3390/ biomedicines 10020255

Academic Editors: Antonio Biondi and Marco Vacante

Received: 5 December 2021

Accepted: 20 January 2022

Published: 25 January 2022

Publisher's Note: MDPI stays neutral with regard to jurisdictional claims in published maps and institutional affiliations.

Copyright: (C) 2022 by the authors. Licensee MDPI, Basel, Switzerland. This article is an open access article distributed under the terms and conditions of the Creative Commons Attribution (CC BY) license (https:// creativecommons.org/licenses/by/ $4.0 /)$.

\author{
Department of Surgery, University of Otago Christchurch, Christchurch 8140, New Zealand; \\ frank.frizelle@otago.ac.nz \\ * Correspondence: jacqui.keenan@otago.ac.nz
}

\begin{abstract}
Colorectal cancer is a leading cause of mortality worldwide. The high incidence and the acceleration of incidence in younger people reinforces the need for better techniques of early detection. The use of noninvasive biomarkers has potential to more accurately inform how patients are prioritised for clinical investigation, which, in turn, may ultimately translate into improved survival for those subsequently found to have curable-stage CRC. This review surveys a wide range of CRC biomarkers that may (alone or in combination) identify symptomatic patients presenting in primary care who should be progressed for clinical investigation.
\end{abstract}

Keywords: colorectal cancer; biomarker; diagnosis; early stage; noninvasive testing

\section{Introduction}

Colorectal cancer (CRC) is a leading cause of mortality worldwide. While western countries continue to have the highest rates of CRC, acceleration of CRC incidence is increasingly reported in in newly industrialised countries as these societies have become more westernised [1]. Most of these cancers are considered sporadic and current thinking is that their development is driven by an environmental and/or lifestyle factor(s) that promotes chronic inflammation and/or DNA damage with associated changes in the microcellular environment, resulting in pre-cancerous and finally cancerous changes [2] This is reinforced by the observation that people who migrate from low- to high-risk areas of the world rapidly assume the CRC risk of the host country [3], A growing awareness of the rapidly increasing burden on left sided cancers in those under 50, that looks likely to result in 1 in 4 rectal cancers being found in patients under 50 in ten years' time [4] gains significance as diets in developing countries become increasingly westernised [5].

CRC is usually surgically curable in the early stages (I and II) of the disease, with a 5 -year relative survival of about $90 \%$ [6]. The key to a good prognosis is early diagnosis. This remains an issue however, not least because patients with early-stage disease have no symptoms or present with nonspecific symptoms in primary care may require multiple visits before referral for investigation. This is of particular concern in young patients. While colonoscopy remains the gold standard procedure used to formulate the diagnosis of CRC based on endoscopic and histopathological assessment, the availability of endoscopy time in most public health systems is limited, resulting in triaging of referrals for colonoscopy. The nonspecific nature of many gastrointestinal symptoms means many patients have a normal colonoscopy [7]. Increasingly, the use of noninvasive biomarkers is being investigated for their potential to more accurately inform how patients are prioritised for clinical investigation, which, in turn, may ultimately translate into improved survival for those subsequently found to have curable-stage CRC.

These biomarkers include proteins and metabolites released by various cells during an active disease state, or more complex biomarkers involving multilevel "omics" to detect cell-associated genetic markers and/or dysbiosis of gut microbiota. They are assessed in a range of biological samples including blood, faeces, urine, breath and, more recently, colonic mucus [8]. Ideally, biomarker testing should be easily performed and relatively 
inexpensive [9]. However, if biomarkers are to accurately identify those individuals with potentially significant pathology, these tests also need to be sensitive and specific to reduce overdiagnosis [10]. This may relate, in part, to the sample type being analysed. For example, the measurement of a biomarker in a faecal sample is more likely to be specific for early-stage colon cancer than the same biomarker measured in blood [11]. Another major consideration is the threshold at which a test is reported.

CRC is essentially a heterogeneous disease comprising different molecular subtypes [12] that can be found in different anatomical locations [13] and at different stages [14]. Adding more complexity is the fact that while some biomarkers also detect precancerous lesions that include adenomas and sessile serrated polyps, the size and/or number of these lesions has the potential to impact on the test sensitivity, as does the level of dysplasia. Accordingly, a potential biomarker that detects early-stage disease in one individual may lack the sensitivity to detect disease in another. To address this, combinations of biomarkers are being investigated as a means to cover a range of host responses that may signal early-stage disease with the goal that this approach may more accurately identify those patients who should be referred for colonoscopy.

The aim of this review is to consider a range of protein, metabolic, molecular and bacterial biomarkers (detailed in Table 1) for their ability to identify symptomatic patients presenting in primary care who should be progressed for clinical investigation.

\section{Faecal Haemoglobin}

Of all symptoms, rectal bleeding is most strongly associated with CRC diagnosis, and testing for blood in faeces has been used to assess symptomatic patients in primary care for many years. Faecal immunochemical tests (FIT) for haemoglobin provide a higher sensitivity than the original guaiac test for faecal occult blood (FOB), and allow for quantification of faecal haemoglobin (f- $\mathrm{Hb}$ ). However, a lack of standardisation makes comparisons across studies that report FIT difficult. Notably the reporting of $\mathrm{f}-\mathrm{Hb}$ present in the collection or measurement solution (which can differ across different FIT products) rather than quantity of $\mathrm{f}-\mathrm{Hb}$ present [15]. Less well appreciated with regards to the test itself is evidence of inter product variability $[7,16]$, an issue that potentially gains even more significance as pointof-care testing increases [17]. The use of different $\mathrm{f}-\mathrm{Hb}$ cut-off concentrations is another confounding factor. As f-Hb cut-off is increased, positivity rate, neoplasia detection rate and sensitivity decrease, while positive predictive value and specificity increase [18], as evidenced by two meta-analyses that indicate the widely varying sensitivity in a screening setting that reflects FIT threshold $[7,19]$. Collectively, these issues highlight the need for this test to be standardised, particularly in symptomatic patients where the first objective is to rule out CRC. When this is addressed, Westwood and colleagues [7] suggest that FIT has the potential to correctly rule out CRC and avoid colonoscopy in $75-80 \%$ of symptomatic patients. Based on these findings, the National Institute for Health and Care Excellence (NICE) diagnostic guidelines now recommend a threshold of $10 \mu \mathrm{g} \mathrm{Hb} / \mathrm{g}$ faeces to guide referral for colorectal cancer in primary care [20].

There are a growing number of studies that report using FIT in symptomatic patients as a means to identify advanced colorectal neoplasia [21-28], and the diagnostic accuracy of FIT at a threshold of $10 \mu \mathrm{g} \mathrm{Hb} / \mathrm{g}$ faeces in this setting is becoming clear (Table 2). A prediction model for CRC detection in symptomatic patients based on FIT concentration, age and sex may further aid diagnosis [29]. One concern, however, is the small proportion of patients found at colonoscopy to have $\mathrm{CRC}$, despite no evidence of $\mathrm{f}-\mathrm{Hb}$, even when the cut-off for the test is reduced to the lowest limit of detection (f-Hb $<2 \mu \mathrm{g} / \mathrm{g}$ ) [21,28]. This may, in part, reflect FIT measurement reportedly being significantly higher in leftsided colonic lesions compared with the right side [30,31]. One study that used a slightly higher FIT threshold (17 $\mu \mathrm{g} / \mathrm{g}$ ) found that approximately one-third of stage $1 \mathrm{CRC}$ s were missed [31]. These studies highlight that while valuable as an adjunct to clinical history, FIT is not a diagnostic test in itself to identify all patients with early-stage disease [27]. 


\section{Inflammatory Markers}

Inflammation is considered a hallmark of cancer [32]. Neutrophils play a major role in the release of calprotectin at sites of inflammation, and faecal calprotectin (FC) has long been considered a potential biomarker of colorectal polyps and cancer [33]. However, FC is shown to have limited diagnostic accuracy for identifying patients with CRC, irrespective of stage [33-37] and this is reinforced by studies that have compared the sensitivity and specificity of FC to quantitative FIT in this setting [21,23,30,38,39].

The benefit of measuring FC levels in stool samples of patients who present in primary care with symptoms may instead be linked to the negative predictive value (NPV) of the test in a CRC diagnostic setting. Studies to date report NPV between 97.2-98.7 for CRC, and 93.2-97.2 for high-risk adenomas [21,37,39,40]. NICE guidelines accept a $3 \%$ risk in missing CRC in setting symptom criteria for referral [41], leading to the suggestion that FC concentrations below an established threshold may help rule out younger patients who more commonly present with nonspecific lower GI symptoms [42].

Another inflammatory marker gaining attention as a potential biomarker of early-stage CRC is chitinase-3-like protein 1 (CHI3L1), a glycoprotein produced by cells including macrophages, neutrophils and tumour cells. A large prospective study of patients referred for colonoscopy due to symptoms or other risk factors for CRC found serum CHI3L1 levels independently predict colon cancer in patients without comorbidity [43]. More recently, serum CHI3L1 was reported as having a high diagnostic value (96\% sensitivity, $91.7 \%$ specificity) in diagnosing CRC, although no association with anatomical location or stage of the cancer was observed [44].

The mechanism(s) linking CHI3L1 to CRC are becoming clearer. This glycoprotein reportedly has multiple roles across normal cell growth, proliferation and survival within the colonic epithelium [45]. A finding of high levels of CHI3L1 in colonic biopsies from patients with IBD [46] and CRC [47] links CHI3L1 with inflammation, and this is confirmed by increased Interleukin (IL)-8 secretion in vitro when intestinal epithelial cells are engineered to overexpress CHI3L1 [47]. More recently, a positive correlation between tumour-associated CHI3L1 and IL-8 protein levels with tumour growth has also been reported [48]. Activation of major signalling pathways [49,50] that involve STAT3 signalling [51] are likely to underlie this response, orchestrated by the subsequent recruitment of macrophages to sites of inflammation [52]. Collectively, these preclinical and laboratory-based findings support further investigation of this inflammatory marker in a clinical setting.

\section{Intercellular Stability}

E-cadherin is a calcium-dependent transmembrane glycoprotein key to the formation of adherens junctions between cells, and is considered to act as a signalling hub in colon homeostasis and disease [53]. Loss of E-cadherin function, which is associated with increased cell proliferation [54], can be linked to genetic mutations [55] and/or posttranslational modification of the $C D H 1$ gene that codes for E-cadherin [56]. However, it may also signal a dysfunctional physiological response involving overexpression of cell-surfaceassociated proteases, leading to dysregulation of cell signalling pathways [57] and/or the presence of specific protease-producing bacterial species within the gut microbiota $[58,59]$. Irrespective of the mechanism involved, the resultant cleavage of extracellular E-cadherin results in the release of soluble (s)E-cadherin that is shown to bind to cell surface receptors and trigger downstream effects via different cell signalling pathways that have a role in the genesis of CRC $[60,61]$. 
Most studies appear to describe elevated sE-cadherin levels in patients with advanced and metastatic CRC, while levels are usually normal in early-stage disease. Velikova et al. [62] were the first to report elevated sE-cadherin levels in patients with local and metastatic disease, although no significant difference in sE-cadherin concentrations between patients with CRC and a group of healthy subjects was found. Likewise, Weiss et al. [63] reported significantly elevated levels of sE-cadherin in sera from patients with late Stage III and Stage IV carcinomas, and in patients with FAP, however the concentration of sE-cadherin in early-stage cancers did not differ significantly from healthy controls.

In 2012, Okugawa et al. [64] showed increasing concentration of sE-cadherin across 186 colorectal cancers that were categorised by stage. Notably, the concentration of sEcadherin increased significantly in patients presenting with Stage IV disease (9471 \pm 7228$)$ when compared to healthy controls $(4509 \pm 2709 \mathrm{ng} / \mathrm{mL})$. More recently, Zhu et al. [65] confirmed and extended these findings. Significantly higher concentrations of sE-cadherin were detected in the patient cohort $(n=142)$ compared to serum levels in samples collected from 50 healthy controls $(7184 \pm 2931 \mathrm{ng} / \mathrm{mL}$ and $4317 \pm 1687 \mathrm{ng} / \mathrm{mL}$, respectively; $p<0.0001)$. Moreover, in this study, levels of sE-cadherin were found to correlate with UICC classifications I-II and III-IV (6654 $\pm 2556 \mathrm{ng} / \mathrm{mL}$ and $8130 \pm 2767 \mathrm{ng} / \mathrm{mL}$, respectively; $p<0.0001)$. Further analysis determined the area under the receiver operating characteristic (ROC) curve of sE-cadherin was 0.853 for discriminating CRC from healthy controls, and that setting the optimal cut-off point for the ELISA at $5928 \mathrm{ng} / \mathrm{mL}$ resulted in diagnostic sensitivity and specificity of $73.9 \%$ and $80 \%$, respectively. It is interesting to note that the mean sE-cadherin concentrations reported by Okugawa et al. [64] are very similar when the UICC classifications are similarly grouped (I-II and III-IV, $6431 \mathrm{ng} / \mathrm{mL}$ and $7971 \mathrm{ng} / \mathrm{mL}$, respectively). In contrast however, an unrelated study that included 36 patients with CRC reported concentrations of $\mathrm{sE-cadherin} \mathrm{were} \mathrm{as} \mathrm{high} \mathrm{in} \mathrm{patients} \mathrm{with} \mathrm{benign} \mathrm{tumours} \mathrm{as} \mathrm{in}$ patients with CRC [66]. Measuring faecal sE-cadherin may improve the sensitivity of this test with regards to diagnosis of early-stage disease [11].

\section{Metabolic Markers}

Cancer is increasingly considered a metabolic disease as evidence emerges that many oncogenes and tumour suppressors play a key role in cellular metabolism. Three major metabolic pathways (aerobic glycolysis, glutaminolysis and one-carbon metabolism) are reportedly altered in CRC [67], and detection of functional changes in these pathways by the analysis of metabolites is increasingly considered as a means to diagnose early-stage disease [68].

The dimeric M2 isoform of pyruvate kinase (also known as tumour M2-pyruvate kinase and M2-PK), an organ-unspecific biomarker that reflects the metabolic activity and proliferation capacity of any tumour per se $[69,70]$, is one example. Moreover, since M2-PK is the direct target of several oncoproteins including K-ras [71], detection of faceal M2-PK has been suggested to be a more sensitive screening tool for CRC than detection of mutations in the oncogenes themselves [72]. Whereas this approach showed early promise with regards to M2-PK levels as a biomarker of CRC [72], and also potentially disease staging $[38,73]$, variable levels of specificity in subsequent studies have questioned the utility of this biomarker $[38,74,75]$.

This is highlighted by three systematic reviews and meta-analyses of the diagnostic accuracy of faecal M2-PK that found varying levels of sensitivity and specificity $(79.0 \%-80.3 \%$ and $80.0 \%-95.2 \%$, respectively) [76-78]. These findings are reinforced by faecal M2-PK failing to identify precancerous bowel lesions or CRC in a subset of symptomatic patients [79]. M2-PK also has reduced diagnostic sensitivity and specificity for detecting early-stage disease when compared to $\mathrm{f}-\mathrm{Hb}[74,75,78,79]$. It is possible however that this relates, in part, to the assay used to determine M2-PK levels. Tumour cells readily switch between the dimeric and less active tetrameric form of M2-PK to give themselves metabolic flexibility in response to environmental changes $[69,70,80,81]$, whereas the assay only measures the dimeric form of the enzyme [74]. 
Finding metabolic markers that can risk stratify patients with suspected CRC is an area of active investigation. These markers broadly divide into two groups, volatile organic compounds (VOCs) and small metabolites that can be detected using urine, blood and faecal samples. VOCs are also detected in exhaled breath [14,82]. The potential diagnostic accuracy of VOCs for early detection of CRC, exemplified by the sensitivity and specificity of canine scent detection [83], is now reflected in studies that report VOCs in the headspace of urine [23,84,85], breath [86-89], blood [90] and faeces [91-94] (Table 3). There is also evidence that detection of urinary VOCs can improve CRC detection in FIT-negative patients [23]. The development of electronic nose technology [84] may bridge this approach with clinical practice in the future.

The growing number of studies looking for nonvolatile CRC-associated metabolites suggests these will also be used in the future to triage symptomatic patients $[14,95,96]$. However, this approach will not be without challenges. Interindividual differences that reflect host-specific diets and/or gut microbiota will need to be considered [2,97,98], and already a quantitative approach and/or the use of metabolite panels is being reported [99,100]. Secondly, as identified elsewhere, the cost and complexity of these assays will need to be addressed before this approach is introduced into routine clinical practice [14].

\section{Genetic Markers}

Most cases of CRC are due to sporadic genetic and/or epigenetic changes, and it is these changes that drive carcinogenesis down pathways resulting in different disease phenotypes that include microsatellite instability (MSI), chromosomal instability (CSI), and the $\mathrm{CpG}$ island methylator phenotype (CIMP). This means that the substantial genetic heterogeneity inherent in CRC needs to be considered when developing molecular diagnostic methods.

Whereas identifying gene mutations alone in faecal DNA lacks diagnostic accuracy [101], testing for gene-specific methylation is more promising, which may relate to epigenetic changes that occur at an early stage in the precancerous pathway [102]. This has led to development of two commercial assays. The first detects aberrantly methylated $B M P 3$ and NDRG4, mutant KRAS, $\beta$-actin and haemoglobin in a single faecal sample and has a sensitivity of $92.3 \%$ and $69.2 \%$ for detecting CRC and advanced precancerous lesions, respectively [103]. The test, which is marketed as Cologuard ${ }^{\circledR}$ in the USA, is technically complex and costly. However, it is more sensitive and specific than FIT alone [103]. The second commercial assay, which is designed to detect methylated SEPT9 in blood, may also be useful in a diagnostic setting [104], but additional studies are needed to confirm this.

One major limitation of this approach however is that it would need to be broad enough to detect early-stage disease (including premalignant (dysplastic) lesions) in all individuals. Virtually all CRCs have a subset of multiple alterations that drive the initiation and progression of precancerous changes through processes that include the accumulation of epigenetic changes [105]. These changes may be accelerated via the production of bacterial metabolites [106], thus reflecting an individual's gut microbiome and/or diet. The rate of DNA methylation also changes with age, and is reportedly side- and racespecific [107]. Accordingly, epigenetic markers may have greater utility for indicating potential pathways to CRC subtype formation $[12,105,108]$ as opposed to being considered as a means to identify patients presenting in primary care who should be progressed for clinical investigation.

Micro (mi)RNAs are a subclass of small, non-coding RNAs that are gaining attention as molecular biomarkers of early-stage CRC [109]. However, while many have been investigated in this setting [14], some show more promise than others [110]. The concept that a panel of miRNAs will collectively have greater diagnostic accuracy is one area of active investigation [111]. 


\section{Gut Microbiota}

The gut microbiota is increasingly considered to have a role in influencing the biology of $C R C$, and this association is demonstrated using a number of different approaches. The simplest is screening faecal samples for molecular evidence of known bacterial virulence factors considered to have a role in initiating CRC. Enterotoxigenic Bacteroides fragilis (ETBF) express a toxin [112] that is associated with promotion of carcinogenesis in mice [113] and humans [114], However, faecal ETBF lacks the specificity and sensitivity needed of a reliable biomarker in a diagnostic setting $[115,116]$.

Another approach considers the environmental changes in early-stage disease that allow some bacterial species to outcompete others [117], resulting in the development of dysbiosis. This reflects shifts in the relative abundance of some members of the gut microbiota and is associated with progression to adenoma $[118,119]$, adenoma to carcinoma $[120,121]$ and CRC $[122,123]$. Screening for specific taxonomic bacterial markers reveals Fusobacterium nucleatum is significantly increased in faecal samples from patients presenting with adenomas and CRC when compared to healthy controls [124-127]. Moreover, these bacteria are functionally linked to colorectal carcinogenesis [124,128-130]. While it may be possible to predict colon tumorigenesis on the basis of a CRC-associated signature such as molecular evidence of faecal F. nucleatum, this approach does not account for microbial community dynamics [131] that are informed by factors including diet, repeated antibiotic exposure, stress and/or exposure to pathogens [132-134]. Additionally, host miRNAs may also affect the growth and composition of the gut microbiota [135]. Long-term, these environment-and/or host-associated changes can result in a shift in bacterial abundance where some species are better or less able to use limiting resources than others [136], as evidenced by the analysis of bacterial metabolites $[96,98]$ that, in turn, may contribute downstream to epigenetic modification [106].

\section{Combinations of Biomarkers}

Assaying for the presence of $\mathrm{fHb}$ in stool samples is widely considered the gold standard test to identify symptomatic patients who should be progressed to clinical investigation. However, even at a low threshold, the FIT test still does not identify all symptomatic patients presenting with early-stage disease. Combinations of biomarkers are increasingly seen as a way to address this. For example, the Cologuard test that screens for molecular markers of early stage disease also includes the measurement of faecal haemoglobin [103]. A comparison of the Cologuard test versus FIT alone clearly shows the increased diagnostic accuracy with this combined approach (Table 4).

There are other studies that also show diagnostic accuracy is increased when a second biomarker is used in addition to FIT (Table 4). For example, measuring M2-PK in faecal samples associates this biomarker with CRC (sensitivity, 87\%, NPV, 96\%) at a cut off of $4 \mathrm{U} / \mathrm{mL}$. However, when tested over a range of concentrations $(4,10$ and $15 \mathrm{U} / \mathrm{mL})$, any positive test combined with FIT resulted in the overall sensitivity increasing to $91.5 \%$, with an NPV of $97 \%$ [38]. The recent study by Cruz et al. [137] confirms this approach has greater diagnostic accuracy than reporting either FIT or M2-PK alone. Screening for urinary VOCs is also shown to improve detection of CRC in symptomatic patients who are FIT-negative [23] (Table 4).

Individual bacterial species may likewise signal risk, as illustrated by Baxter et al. [138] who showed detection of colonic lesions increased when the relative abundance of certain strains of gut microbiota was assessed in combination with FIT. This study suggested an association of $F$. nucelatum with CRC, and subsequent studies confirm quantitation of $F$. nucleatum in faecal samples in combination with FIT increases diagnostic accuracy over FIT alone in detecting CRC [126] and advanced adenomas [127] (Table 4). In contrast, detecting FC in combination with FIT appears to add little or no additional diagnostic information $[21,23,38,39]$ (Table 4). 


\section{Concluding Remarks}

An FIT with a threshold of $10 \mathrm{ug} \mathrm{Hb} / \mathrm{g}$ faeces clearly has utility as a first-line test for identifying symptomatic patients who should be progressed for definitive clinical investigation. However, this test does not detect everyone with early-stage disease, and, as detailed above, there are a growing number of molecular, protein and chemical based approaches that could be tested in combination with FIT to increase diagnostic accuracy. What is becoming apparent is the interconnectedness between many of these biomarkers, as evidenced by CHI3L1-mediated suppression of E-cadherin expression [139], microbiotaderived metabolite involvement in epigenetic alteration [140], and the effect of miRNA in the growth and composition of the gut microbiota [141], which may contribute to the reported role of miRNA-associated colon carcinogenesis [110]. This is a rapidly evolving area of research, and in the future it is likely that combinations of biomarkers may be able to detect dysplastic lesions that can be treated at a low cost to both the patient and health providers.

Table 1. Noninvasive biomarkers.

\begin{tabular}{ccc}
\hline Indicator Type & Biomarker & References \\
\hline Tissue damage & Faecal haemoglobin & {$[7,33-51]$} \\
Inflammation & Calprotectin & {$[21,23,30,33-42]$} \\
Intercellular stability & Chitinase 3-like 1 & {$[43-51]$} \\
Metabolic & E-cadherin & {$[53-66]$} \\
& M2-pyruvate kinase & {$[38,69-81]$} \\
Host genetics & Volatile organic compounds & {$[14,23,82-94]$} \\
Gut microbiota & Small metabolites & {$[14,95-100]$} \\
& Genetic and/or epigenetic markers & {$[14,105-104]$} \\
& MicroRNA & {$[120-126]$}
\end{tabular}

Table 2. Diagnostic characteristic of FIT $\geq 10 \mu \mathrm{g} \mathrm{Hb} / \mathrm{g}$ faeces in symptomatic patients.

\begin{tabular}{|c|c|c|c|c|c|c|}
\hline Study & $n$ & Disease & Sensitivity (\%) & Specificity (\%) & PPV & NPV \\
\hline \multirow{2}{*}{ Mowat et.al. 2016 [21] } & \multirow{2}{*}{1043} & CRC $(n=28)$ & 89.3 & 79.1 & 14.2 & 99.5 \\
\hline & & HRA $(n=41)$ & 50.0 & 78.0 & 11.4 & 96.5 \\
\hline \multirow{2}{*}{ Widlak et al. 2018 [23] } & \multirow{2}{*}{562} & CRC $(n=35)$ & 80 & 93 & 44 & 99 \\
\hline & & HRA $(n=27)$ & 63 & 76 & 11 & 98 \\
\hline \multirow{2}{*}{ D'Souza et al. 2021 [28] } & \multirow{2}{*}{9822} & CRC $(n=329)$ & 90.9 & 83.5 & 16.1 & 99.6 \\
\hline & & HRA $(n=421)$ & 45.4 & 82.2 & 10.3 & 97.1 \\
\hline
\end{tabular}

FIT, faecal immunochemical test for haemoglobin; PPV, positive predictive value; NPV, negative predictive value; HRA, high-risk adenoma. 
Table 3. Volatile organic compounds (VOCs) used for CRC and advanced adenoma detection.

\begin{tabular}{|c|c|c|c|c|c|}
\hline Study Setting & Sample Type & Biomarker(s) & Sensitivity (\%) & Specificity (\%) & Ref. \\
\hline Case-control & Stool & VOC patterns-detected by electronic nose & $\begin{array}{l}85(\mathrm{CRC}) \\
62(\mathrm{AA})\end{array}$ & $\begin{array}{l}87(\mathrm{CRC}) \\
86(\mathrm{AA})\end{array}$ & [91] \\
\hline FOBT+ & Stool & $\begin{array}{l}\text { Hydrogen sulphide, dimethyl sulphide, } \\
\text { dimethyl disulphide-detected by SIFT-MS }\end{array}$ & 72 & 78 & [92] \\
\hline Case-control & Stool & $\begin{array}{l}\text { Methyl mercaptan, hydrogen-detected by } \\
\text { GC }\end{array}$ & 90 & 57.7 & [94] \\
\hline Case-control & Stool & $\begin{array}{c}\text { Propan-2-ol, hexan-2-one-detected by } \\
\text { GC-MS }\end{array}$ & 87.9 & 84.6 & [93] \\
\hline Case-control & Urine & VOC fingerprint-detected by FAIMS & 88 & 60 & [85] \\
\hline Case-control & Urine & VOC fingerprint-detected by FAIMS & 63 & 63 & [23] \\
\hline Case-control & Breath & $\begin{array}{c}\text { Acetone, ethylacetate, ethanol, } \\
\text { 4-methyl-octane-detected by GC-MS }\end{array}$ & 85 & 94 & [86] \\
\hline Case-control & Breath & $\begin{array}{l}\text { Nonanal, decanal, 4-methyl-2-pentanone, } \\
\text { 2-methylbutane, 4-methyloctane, } \\
\text { 4-methylundecane, 2-methylpentane, } \\
\text { 3-methylpentane, methylcyclopentane, } \\
\text { cyclohexane, methylcyclohexane, } \\
\text { trimethylcyclohexane-1,2-pentadiene, } \\
\text { 1,3-dimethylbenzne, } \\
\text { 1,4-dimethylbenzene-detected by GC-MS }\end{array}$ & 86 & 83 & [88] \\
\hline Case-control & Breath & $\begin{array}{c}\text { cyclohexanone, 2,2-dimethyldecane, } \\
\text { dodecane, 4-ethyl-1-octyn-3-ol, } \\
\text { ethylaniline, cyclooctylmethanol, } \\
\text { trans-2-dodecen-1-ol, 3-hydroxy-2,4,4 } \\
\text { trimethylpentyl 2-methylpropanoate, } \\
\text { 6-t-butyl-2,2,9,9-tetramethyl-3,5-decadien- } \\
\text { 7-yne-detected by } \\
\text { SPME-GC/MS }\end{array}$ & & & [87] \\
\hline $\begin{array}{l}\text { Colonoscopy } \\
\text { patients }\end{array}$ & Breath & VOC patterns-detected by electronic nose & $\begin{array}{l}95 \%(\mathrm{CRC}) \\
79 \%(\mathrm{AA})\end{array}$ & $\begin{array}{l}64 \%(\mathrm{CRC}) \\
59 \%(\mathrm{AA})\end{array}$ & [89] \\
\hline
\end{tabular}

CRC, colorectal cancer; AA, advanced adenoma, defined as $\geq 10 \mathrm{~mm}$, with any villous features or high-grade dyspasis); FOBT, faecal occult blood test. SIFT, selected ion flow tube; MS, mass spectrometry; GC, gas chromatography; FAIMS, field asymmetric ion mobility spectrometry; SPME, solid-phase microextraction. 
Table 4. Diagnostic performance of biomarker combination for CRC and high-risk/advanced adenoma.

\begin{tabular}{|c|c|c|c|c|c|c|}
\hline Disease Group & Biomarker(s) & Sensitivity (\%) & Specificity (\%) & PPV (\%) & NPV (\%) & Ref. \\
\hline \multirow{2}{*}{ CRC $(n=65)$} & FIT $^{a}$ & 73.8 & \multirow{2}{*}{94.9} & & & \multirow{4}{*}{ [103] } \\
\hline & Cologuard ${ }^{\circledR}$ & 92.3 & & & & \\
\hline \multirow[t]{2}{*}{ HRA $(n=757)$} & FIT $^{a}$ & 42.2 & \multirow[t]{2}{*}{86.6} & & & \\
\hline & Cologuard $^{\circledR}$ & 23.8 & & & & \\
\hline \multirow{2}{*}{ CRC $(n=18)$} & FIT $^{a}$ & 61.7 & 88.8 & 52.7 & 92 & \multirow{4}{*}{ [38] } \\
\hline & FIT and M2-PK ${ }^{\mathrm{d}}$ & 91.5 & 57.1 & 30.1 & 97.1 & \\
\hline \multirow[t]{2}{*}{$\mathrm{AA}(n=28)$} & FIT $^{a}$ & 35.6 & 94.5 & 85.4 & 62.2 & \\
\hline & FIT and M2-PK & 71.2 & 66.9 & 65.7 & 72.3 & \\
\hline \multirow{3}{*}{ CRC $(n=60)$} & FIT $^{b}$ & 91.5 & 72.3 & & & \multirow{3}{*}{ [134] } \\
\hline & FIT and M2-PK ${ }^{\mathrm{e}}$ & 49.1 & 93.5 & & & \\
\hline & FIT or M2-PK & 96.6 & 58.2 & & & \\
\hline \multirow{2}{*}{ CRC $(n=35)$} & $\mathrm{FIT}^{\mathrm{c}}$ & 80 & 93 & \multirow{2}{*}{44} & 99 & \multirow{2}{*}[23]{} \\
\hline & VOCs (FIT -ve) & 97 & 72 & & 100 & \\
\hline \multirow{2}{*}{ CRC $(n=104)$} & FIT $^{a}$ & 73.1 & 98 & & & \multirow{4}{*}{ [123] } \\
\hline & FIT and $F n$. & 92.3 & 93 & & & \\
\hline \multirow{2}{*}{$\mathrm{AA}(n=103)$} & FIT $^{a}$ & 15.5 & 98 & & & \\
\hline & FIT and $F n$ & 38.6 & 89 & & & \\
\hline \multirow{2}{*}{ CRC $(n=18)$} & FIT $^{a}$ & 61.7 & 88.8 & 52.7 & 92 & \multirow{4}{*}[38]{} \\
\hline & FIT and/or FC ${ }^{f}$ & 95.7 & 26.4 & 22.1 & 96.6 & \\
\hline \multirow[t]{2}{*}{ AA $(n=28)$} & FIT $^{a}$ & 35.6 & 94.5 & 85.4 & 62.2 & \\
\hline & FIT and/or FC & 82.8 & 26.9 & 49.5 & 64.4 & \\
\hline \multirow{2}{*}{ CRC $(n=35)$} & FIT $^{\mathrm{c}}$ & 80 & 93 & 44 & 99 & \multirow{4}{*}{ [23] } \\
\hline & FIT and FC & 80 & 93 & 43 & 99 & \\
\hline \multirow[t]{2}{*}{ HRA $(n=27)$} & FIT $^{\mathrm{c}}$ & 63 & 76 & 11 & 98 & \\
\hline & FIT and FC & 93 & 25 & 6 & 99 & \\
\hline \multirow{2}{*}{$\operatorname{CRC}(n=28)$} & FIT $^{a}$ & 89.3 & 79.1 & 14.2 & 99.5 & \multirow{4}{*}{ [21] } \\
\hline & FIT and/or FC $\mathrm{g}$ & 100 & 20.3 & 4.7 & 100 & \\
\hline \multirow[t]{2}{*}{$\operatorname{HRA}(n=41)$} & FIT $^{a}$ & 50 & 78 & 11.4 & 96.5 & \\
\hline & FIT and/or FC & 92.7 & 20.3 & 6.3 & 97.7 & \\
\hline \multirow{2}{*}{ CRC $(n=16)$} & FIT $^{a}$ & 87.5 & 83.7 & 18.2 & 99.4 & \multirow{4}{*}{ [39] } \\
\hline & FIT and $\mathrm{FC}^{\mathrm{g}}$ & 93.8 & 43.3 & 6.4 & 99.4 & \\
\hline \multirow[t]{2}{*}{ AA $(n=39)$} & FIT $^{\mathrm{a}}$ & 46.2 & 83.8 & 23.4 & 93.6 & \\
\hline & FIT and FC & 82 & 44.4 & 13.6 & 98.9 & \\
\hline
\end{tabular}

HRA, high-risk adenomas; AA, advanced adenomas; Faecal immunochemical test (FIT) cut-off: ${ }^{\text {, }} 20$ ug; ${ }^{\text {, }}, 10 \mu$; c, $3 \mu \mathrm{g} \mathrm{f-Hb} / \mathrm{g}$ stool; M2-PK cut-off values: ${ }^{\mathrm{d}}, 4,10, \& 15 \mathrm{U} / \mathrm{mL} ;{ }^{\mathrm{e}}, 8 \mathrm{U} / \mathrm{mL}$; Faecal calprotectin (FC) cut-offs: ${ }^{\mathrm{f}}, 50$ and $416 \mu \mathrm{g} / \mathrm{g}$; $\mathrm{g}, 50 \mu \mathrm{g} / \mathrm{g}$; VOCs, volatile organic compounds; Fn, Fusobacterium nucleatum.

Funding: This research received no external funding.

Data Availability Statement: Not applicable.

Conflicts of Interest: The authors declare no conflict of interest.

\section{References}

1. Bray, F.; Ferlay, J.; Soerjomataram, I.; Siegel, R.L.; Torre, L.A.; Jemal, A. Global cancer statistics 2018: GLOBOCAN estimates of incidence and mortality worldwide for 36 cancers in 185 countries. CA Cancer J. Clin. 2018, 68, 394-424. [CrossRef] [PubMed]

2. Keenan, J.I.; Frizelle, F.A. Toxigenic gut bacteria, diet and colon carcinogenesis. J. R. Soc. N. Z. 2020, 50, 418-433. [CrossRef] 
3. Flood, D.M.; Weiss, N.S.; Cook, L.S.; Emerson, J.C.; Schwartz, S.M.; Potter, J.D. Colorectal cancer incidence in Asian migrants to the United States and their descendants. Cancer Causes Control 2000, 11, 403-411. [CrossRef] [PubMed]

4. REACCT Collaborative; Zaborowski, A.M.; Abdile, A.; Adamina, M.; Aigner, F.; d'Allens, L.; Allmer, C.; Alvarez, A.; Anula, R.; Andric, M.; et al. Characteristics of Early-Onset vs. Late-Onset Colorectal Cancer: A Review. JAMA Surg. 2021, 156, 865-874. [CrossRef]

5. Keenan, J.; Aitchison, A.; Frizelle, F. Are young people eating their way to bowel cancer? N. Z. Med. J. 2017, 130, 90-92.

6. Buchwald, P.; Hall, C.; Davidson, C.; Dixon, L.; Dobbs, B.; Robinson, B.; Frizelle, F. Improved survival for rectal cancer compared to colon cancer: The four cohort study. ANZ J. Surg. 2018, 88, E114-E117. [CrossRef]

7. Westwood, M.; Lang, S.; Armstrong, N.; van Turenhout, S.; Cubiella, J.; Stirk, L.; Ramos, I.C.; Luyendijk, M.; Zaim, R.; Kleijnen, J.; et al. Faecal immunochemical tests (FIT) can help to rule out colorectal cancer in patients presenting in primary care with lower abdominal symptoms: A systematic review conducted to inform new NICE DG30 diagnostic guidance. BMC Med. 2017, 15, 189. [CrossRef]

8. Loktionov, A.; Soubieres, A.; Bandaletova, T.; Francis, N.; Allison, J.; Sturt, J.; Mathur, J.; Poullis, A. Biomarker measurement in non-invasively sampled colorectal mucus as a novel approach to colorectal cancer detection: Screening and triage implications. Br. J. Cancer 2020, 123, 252-260. [CrossRef]

9. Sands, B.E. Biomarkers of Inflammation in Inflammatory Bowel Disease. Gastroenterology 2015, 149, 1275-1285.e2. [CrossRef]

10. Srivastava, S.; Koay, E.J.; Borowsky, A.D.; De Marzo, A.M.; Ghosh, S.; Wagner, P.D.; Kramer, B.S. Cancer overdiagnosis: A biological challenge and clinical dilemma. Nat. Rev. Cancer 2019, 19, 349-358. [CrossRef]

11. Dickinson, B.T.; Kisiel, J.; Ahlquist, D.A.; Grady, W.M. Molecular markers for colorectal cancer screening. Gut 2015, 64, 1485-1494. [CrossRef] [PubMed]

12. Guinney, J.; Dienstmann, R.; Wang, X.; de Reynies, A.; Schlicker, A.; Soneson, C.; Marisa, L.; Roepman, P.; Nyamundanda, G.; Angelino, P.; et al. The consensus molecular subtypes of colorectal cancer. Nat. Med. 2015, 21, 1350-1356. [CrossRef] [PubMed]

13. Iacopetta, B. Are there two sides to colorectal cancer? Int. J. Cancer 2002, 101, 403-408. [CrossRef]

14. Loktionov, A. Biomarkers for detecting colorectal cancer non-invasively: DNA, RNA or proteins? World J. Gastrointest. Oncol. 2020, 12, 124-148. [CrossRef] [PubMed]

15. Allison, J.E.; Fraser, C.G.; Halloran, S.P.; Young, G.P. Comparing fecal immunochemical tests: Improved standardization is needed. Gastroenterology 2012, 142, 422-424. [CrossRef]

16. Brenner, H.; Haug, U.; Hundt, S. Inter-test agreement and quantitative cross-validation of immunochromatographical fecal occult blood tests. Int. J. Cancer 2010, 127, 1643-1649. [CrossRef]

17. Levy, B.T.; Daly, J.M.; Xu, Y.; Crockett, S.D.; Hoffman, R.M.; Dawson, J.D.; Parang, K.; Shokar, N.K.; Reuland, D.S.; Zuckerman, M.J.; et al. Comparative effectiveness of five fecal immunochemical tests using colonoscopy as the gold standard: Study protocol. Contemp. Clin. Trials 2021, 106, 106430. [CrossRef]

18. Fraser, C.G. Interpretation of faecal haemoglobin concentration data in colorectal cancer screening and in assessment of symptomatic patients. J. Lab. Precis. Med. 2017, 2, 12. [CrossRef]

19. Lee, J.K.; Liles, E.G.; Bent, S.; Levin, T.R.; Corley, D.A. Accuracy of fecal immunochemical tests for colorectal cancer: Systematic review and meta-analysis. Ann. Intern. Med. 2014, 160, 171. [CrossRef]

20. NICE. Quantitative Faecal Immunochemical Tests to Guide Referral for Colorectal Cancer in Primary Care [DG30]; National Institute for Health and Care Excellence: London, UK, 2017.

21. Mowat, C.; Digby, J.; Strachan, J.A.; Wilson, R.; Carey, F.A.; Fraser, C.G.; Steele, R.J. Faecal haemoglobin and faecal calprotectin as indicators of bowel disease in patients presenting to primary care with bowel symptoms. Gut 2016, 65, 1463-1469. [CrossRef]

22. Godber, I.M.; Todd, L.M.; Fraser, C.G.; MacDonald, L.R.; Younes, H.B. Use of a faecal immunochemical test for haemoglobin can aid in the investigation of patients with lower abdominal symptoms. Clin. Chem. Lab. Med. 2016, 54, 595-602. [CrossRef] [PubMed]

23. Widlak, M.M.; Neal, M.; Daulton, E.; Thomas, C.L.; Tomkins, C.; Singh, B.; Harmston, C.; Wicaksono, A.; Evans, C.; Smith, S.; et al Risk stratification of symptomatic patients suspected of colorectal cancer using faecal and urinary markers. Colorectal Dis. 2018, 20, O335-O342. [CrossRef] [PubMed]

24. Navarro, M.; Hijos, G.; Ramirez, T.; Omella, I.; Carrera-Lasfuentes, P.; Lanas, A. Fecal Hemoglobin Concentration, a Good Predictor of Risk of Advanced Colorectal Neoplasia in Symptomatic and Asymptomatic Patients. Front. Med. $2019,6,91$. [CrossRef] [PubMed]

25. Mowat, C.; Digby, J.; Strachan, J.A.; McCann, R.; Hall, C.; Heather, D.; Carey, F.; Fraser, C.G.; Steele, R.J.C. Impact of introducing a faecal immunochemical test (FIT) for haemoglobin into primary care on the outcome of patients with new bowel symptoms: A prospective cohort study. BMJ Open Gastroenterol. 2019, 6, e000293. [CrossRef]

26. Nicholson, B.D.; James, T.; Paddon, M.; Justice, S.; Oke, J.L.; East, J.E.; Shine, B. Faecal immunochemical testing for adults with symptoms of colorectal cancer attending English primary care: A retrospective cohort study of 14,487 consecutive test requests. Aliment. Pharmacol. Ther. 2020, 52, 1031-1041. [CrossRef]

27. MacDonald, S.; MacDonald, L.; Godwin, J.; Macdonald, A.; Thornton, M. The diagnostic accuracy of Faecal Immunohistochemical Test (FIT) in identifying significant bowel disease in a symptomatic population. Colorectal Dis. 2021; Online ahead of print. [CrossRef] 
28. D'Souza, N.; Georgiou Delisle, T.; Chen, M.; Benton, S.; Abulafi, M.; Group, N.F.S. Faecal immunochemical test is superior to symptoms in predicting pathology in patients with suspected colorectal cancer symptoms referred on a $2 \mathrm{WW}$ pathway: A diagnostic accuracy study. Gut 2021, 70, 1130-1138. [CrossRef]

29. Cubiella, J.; Digby, J.; Rodriguez-Alonso, L.; Vega, P.; Salve, M.; Diaz-Ondina, M.; Strachan, J.A.; Mowat, C.; McDonald, P.J.; Carey, F.A.; et al. The fecal hemoglobin concentration, age and sex test score: Development and external validation of a simple prediction tool for colorectal cancer detection in symptomatic patients. Int. J. Cancer 2017, 140, 2201-2211. [CrossRef]

30. Widlak, M.M.; Thomas, C.L.; Thomas, M.G.; Tomkins, C.; Smith, S.; O'Connell, N.; Wurie, S.; Burns, L.; Harmston, C.; Evans, C.; et al. Diagnostic accuracy of faecal biomarkers in detecting colorectal cancer and adenoma in symptomatic patients. Aliment. Pharmacol. Ther. 2017, 45, 354-363. [CrossRef]

31. Niedermaier, T.; Tikk, K.; Gies, A.; Bieck, S.; Brenner, H. Sensitivity of Fecal Immunochemical Test for Colorectal Cancer Detection Differs According to Stage and Location. Clin. Gastroenterol. Hepatol. 2020, 18, 2920-2928.e6. [CrossRef]

32. Hanahan, D.; Weinberg, R.A. Hallmarks of cancer: The next generation. Cell 2011, 144, 646-674. [CrossRef] [PubMed]

33. Roseth, A.G.; Kristinsson, J.; Fagerhol, M.K.; Schjonsby, H.; Aadland, E.; Nygaard, K.; Roald, B. Faecal calprotectin: A novel test for the diagnosis of colorectal cancer? Scand. J. Gastroenterol. 1993, 28, 1073-1076. [CrossRef] [PubMed]

34. Tibble, J.; Sigthorsson, G.; Foster, R.; Sherwood, R.; Fagerhol, M.; Bjarnason, I. Faecal calprotectin and faecal occult blood tests in the diagnosis of colorectal carcinoma and adenoma. Gut 2001, 49, 402-408. [CrossRef] [PubMed]

35. Summerton, C.B.; Longlands, M.G.; Wiener, K.; Shreeve, D.R. Faecal calprotectin: A marker of inflammation throughout the intestinal tract. Eur. J. Gastroenterol. Hepatol. 2002, 14, 841-845. [CrossRef] [PubMed]

36. von Roon, A.C.; Karamountzos, L.; Purkayastha, S.; Reese, G.E.; Darzi, A.W.; Teare, J.P.; Paraskeva, P.; Tekkis, P.P. Diagnostic precision of fecal calprotectin for inflammatory bowel disease and colorectal malignancy. Am. J. Gastroenterol. 2007, 102, 803-813. [CrossRef]

37. Kan, Y.M.; Chu, S.Y.; Loo, C.K. Diagnostic accuracy of fecal calprotectin in predicting significant gastrointestinal diseases. JGH Open 2021, 5, 647-652. [CrossRef]

38. Parente, F.; Marino, B.; Ilardo, A.; Fracasso, P.; Zullo, A.; Hassan, C.; Moretti, R.; Cremaschini, M.; Ardizzoia, A.; Saracino, I.; et al A combination of faecal tests for the detection of colon cancer: A new strategy for an appropriate selection of referrals to colonoscopy? A prospective multicentre Italian study. Eur. J. Gastroenterol. Hepatol. 2012, 24, 1145-1152. [CrossRef]

39. Lue, A.; Hijos, G.; Sostres, C.; Perales, A.; Navarro, M.; Barra, M.V.; Mascialino, B.; Andalucia, C.; Puente, J.J.; Lanas, Á.; et al. The combination of quantitative faecal occult blood test and faecal calprotectin is a cost-effective strategy to avoid colonoscopies in symptomatic patients without relevant pathology. Therap. Adv. Gastroenterol. 2020, 13, 1756284820920786. [CrossRef]

40. Turvill, J.; Aghahoseini, A.; Sivarajasingham, N.; Abbas, K.; Choudhry, M.; Polyzois, K.; Lasithiotakis, K.; Volanaki, D.; Kim, B.; Langlands, F.; et al. Faecal calprotectin in patients with suspected colorectal cancer: A diagnostic accuracy study. Br. J. Gen. Pract. 2016, 66, e499-e506. [CrossRef]

41. NICE. Suspected Cancer: Recognition and Referral; National Institute for Health and Care Excellence: London, UK, 2015.

42. Chuter, C.; Keding, A.; Holmes, H.; Turnock, D.; Turvill, J. Getting the best out of faecal immunochemical tests and faecal calprotectin. Frontline Gastroenterol. 2020, 11, 414-416. [CrossRef] [PubMed]

43. Johansen, J.S.; Christensen, I.J.; Jorgensen, L.N.; Olsen, J.; Rahr, H.B.; Nielsen, K.T.; Laurberg, S.; Brunner, N.; Nielsen, H.J. Serum YKL-40 in risk assessment for colorectal cancer: A prospective study of 4496 subjects at risk of colorectal cancer. Cancer Epidemiol. Biomark. Prev. 2015, 24, 621-626. [CrossRef] [PubMed]

44. Eldaly, M.N.; Metwally, F.M.; Shousha, W.G.; El-Saiid, A.S.; Ramadan, S.S. Clinical Potentials of miR-576-3p, miR-613, NDRG2 and YKL40 in Colorectal Cancer Patients. Asian Pac. J. Cancer Prev. 2020, 21, 1689-1695. [CrossRef] [PubMed]

45. Zhao, T.; Su, Z.; Li, Y.; Zhang, X.; You, Q. Chitinase-3 like-protein-1 function and its role in diseases. Signal Transduct. Target. Ther. 2020, 5, 201. [CrossRef] [PubMed]

46. Mizoguchi, E. Chitinase 3-like-1 exacerbates intestinal inflammation by enhancing bacterial adhesion and invasion in colonic epithelial cells. Gastroenterology 2006, 130, 398-411. [CrossRef]

47. Kawada, M.; Seno, H.; Kanda, K.; Nakanishi, Y.; Akitake, R.; Komekado, H.; Kawada, K.; Sakai, Y.; Mizoguchi, E.; Chiba, T. Chitinase 3-like 1 promotes macrophage recruitment and angiogenesis in colorectal cancer. Oncogene 2012, 31, 3111-3123. [CrossRef]

48. Calu, V.; Ionescu, A.; Stanca, L.; Geicu, O.I.; Iordache, F.; Pisoschi, A.M.; Serban, A.I.; Bilteanu, L. Key biomarkers within the colorectal cancer related inflammatory microenvironment. Sci. Rep. 2021, 11, 7940. [CrossRef]

49. Eurich, K.; Segawa, M.; Toei-Shimizu, S.; Mizoguchi, E. Potential role of chitinase 3-like-1 in inflammation-associated carcinogenic changes of epithelial cells. World J. Gastroenterol. 2009, 15, 5249-5259. [CrossRef]

50. Chen, C.C.; Pekow, J.; Llado, V.; Kanneganti, M.; Lau, C.W.; Mizoguchi, A.; Mino-Kenudson, M.; Bissonnette, M.; Mizoguchi, E. Chitinase 3-like-1 expression in colonic epithelial cells as a potentially novel marker for colitis-associated neoplasia. Am. J. Pathol. 2011, 179, 1494-1503. [CrossRef]

51. Tran, H.T.; Lee, I.A.; Low, D.; Kamba, A.; Mizoguchi, A.; Shi, H.N.; Lee, C.G.; Elias, J.A.; Mizoguchi, E. Chitinase 3-like 1 synergistically activates IL6-mediated STAT3 phosphorylation in intestinal epithelial cells in murine models of infectious colitis. Inflamm. Bowel Dis. 2014, 20, 835-846. [CrossRef]

52. Wang, H.; Tian, T.; Zhang, J. Tumor-Associated Macrophages (TAMs) in Colorectal Cancer (CRC): From Mechanism to Therapy and Prognosis. Int. J. Mol. Sci. 2021, 22, 8470. [CrossRef] 
53. Daulagala, A.C.; Bridges, M.C.; Kourtidis, A. E-cadherin Beyond Structure: A Signaling Hub in Colon Homeostasis and Disease. Int. J. Mol. Sci. 2019, 20, 2756. [CrossRef] [PubMed]

54. Wodarz, A.; Nathke, I. Cell polarity in development and cancer. Nat. Cell Biol. 2007, 9, 1016-1024. [CrossRef] [PubMed]

55. Aitchison, A.; Hakkaart, C.; Whitehead, M.; Khan, S.; Siddique, S.; Ahmed, R.; Frizelle, F.A.; Keenan, J.I. CDH1 gene mutation in early-onset, colorectal signet-ring cell carcinoma. Pathol. Res. Pract. 2020, 216, 152912. [CrossRef] [PubMed]

56. Serrano-Gomez, S.J.; Maziveyi, M.; Alahari, S.K. Regulation of epithelial-mesenchymal transition through epigenetic and post-translational modifications. Mol. Cancer 2016, 15, 18. [CrossRef]

57. Maretzky, T.; Reiss, K.; Ludwig, A.; Buchholz, J.; Scholz, F.; Proksch, E.; de Strooper, B.; Hartmann, D.; Saftig, P. ADAM10 mediates E-cadherin shedding and regulates epithelial cell-cell adhesion, migration, and beta-catenin translocation. Proc. Natl. Acad. Sci. USA 2005, 102, 9182-9187. [CrossRef]

58. Hoy, B.; Geppert, T.; Boehm, M.; Reisen, F.; Plattner, P.; Gadermaier, G.; Sewald, N.; Ferreira, F.; Briza, P.; Schneider, G.; et al Distinct roles of secreted HtrA proteases from gram-negative pathogens in cleaving the junctional protein and tumor suppressor E-cadherin. J. Biol. Chem. 2012, 287, 10115-10120. [CrossRef]

59. Wu, S.; Rhee, K.J.; Zhang, M.; Franco, A.; Sears, C.L. Bacteroides fragilis toxin stimulates intestinal epithelial cell shedding and gamma-secretase-dependent E-cadherin cleavage. J. Cell Sci. 2007, 120 Pt 11, 1944-1952. [CrossRef]

60. David, J.M.; Rajasekaran, A.K. Dishonorable discharge: The oncogenic roles of cleaved E-cadherin fragments. Cancer Res. 2012, 72, 2917-2923. [CrossRef]

61. Hu, Q.P.; Kuang, J.Y.; Yang, Q.K.; Bian, X.W.; Yu, S.C. Beyond a tumor suppressor: Soluble E-cadherin promotes the progression of cancer. Int. J. Cancer 2016, 138, 2804-2812. [CrossRef]

62. Velikova, G.; Banks, R.E.; Gearing, A.; Hemingway, I.; Forbes, M.A.; Preston, S.R.; Hall, N.R.; Jones, M.; Wyatt, J.; Miller, K.; et al. Serum concentrations of soluble adhesion molecules in patients with colorectal cancer. Br. J. Cancer 1998, 77, 1857-1863. [CrossRef]

63. Weiss, J.V.; Klein-Scory, S.; Kubler, S.; Reinacher-Schick, A.; Stricker, I.; Schmiegel, W.; Schwarte-Waldhoff, I. Soluble E-cadherin as a serum biomarker candidate: Elevated levels in patients with late-stage colorectal carcinoma and FAP. Int. J. Cancer 2011, 128, 1384-1392. [CrossRef] [PubMed]

64. Okugawa, Y.; Toiyama, Y.; Inoue, Y.; Iwata, T.; Fujikawa, H.; Saigusa, S.; Konishi, N.; Tanaka, K.; Uchida, K.; Kusunoki, M. Clinical significance of serum soluble E-cadherin in colorectal carcinoma. J. Surg. Res. 2012, 175, e67-e73. [CrossRef] [PubMed]

65. Zhu, S.; Zhao, G.; Zhao, X.; Zhan, X.; Cai, M.; Geng, C.; Pu, Q.; Zhao, Q.; Fu, Q.; Huang, C.; et al. Elevated soluble E-cadherin during the epithelial-mesenchymal transition process and as a diagnostic marker in colorectal cancer. Gene 2020, 754, 144899. [CrossRef] [PubMed]

66. Wilmanns, C.; Grossmann, J.; Steinhauer, S.; Manthey, G.; Weinhold, B.; Schmitt-Graff, A.; von Specht, B.U. Soluble serum E-cadherin as a marker of tumour progression in colorectal cancer patients. Clin. Exp. Metastasis 2004, 21, 75-78. [CrossRef]

67. Boroughs, L.K.; DeBerardinis, R.J. Metabolic pathways promoting cancer cell survival and growth. Nat. Cell Biol. 2015, 17, 351-359. [CrossRef]

68. Wishart, D.S. Is Cancer a Genetic Disease or a Metabolic Disease? EBioMedicine 2015, 2, 478-479. [CrossRef]

69. Mazurek, S. Pyruvate kinase type M2: A key regulator of the metabolic budget system in tumor cells. Int. J. Biochem. Cell Biol. 2011, 43, 969-980. [CrossRef]

70. Dayton, T.L.; Jacks, T.; Vander Heiden, M.G. PKM2, cancer metabolism, and the road ahead. EMBO Rep. 2016, 17, 1721-1730. [CrossRef]

71. Mazurek, S.; Zwerschke, W.; Jansen-Durr, P.; Eigenbrodt, E. Metabolic cooperation between different oncogenes during cell transformation: Interaction between activated ras and HPV-16 E7. Oncogene 2001, 20, 6891-6898. [CrossRef]

72. Hardt, P.D.; Mazurek, S.; Toepler, M.; Schlierbach, P.; Bretzel, R.G.; Eigenbrodt, E.; Kloer, H.U. Faecal tumour M2 pyruvate kinase: A new, sensitive screening tool for colorectal cancer. Br. J. Cancer 2004, 91, 980-984. [CrossRef]

73. Haug, U.; Rothenbacher, D.; Wente, M.N.; Seiler, C.M.; Stegmaier, C.; Brenner, H. Tumour M2-PK as a stool marker for colorectal cancer: Comparative analysis in a large sample of unselected older adults vs colorectal cancer patients. Br. J. Cancer 2007, 96 1329-1334. [CrossRef] [PubMed]

74. Shastri, Y.M.; Naumann, M.; Oremek, G.M.; Hanisch, E.; Rosch, W.; Mossner, J.; Caspary, W.F.; Stein, J.M. Prospective multicenter evaluation of fecal tumor pyruvate kinase type M2 (M2-PK) as a screening biomarker for colorectal neoplasia. Int. J. Cancer 2006, 119, 2651-2656. [CrossRef] [PubMed]

75. Shastri, Y.M.; Loitsch, S.; Hoepffner, N.; Povse, N.; Hanisch, E.; Rosch, W.; Mossner, J.; Stein, J.M. Comparison of an established simple office-based immunological FOBT with fecal tumor pyruvate kinase type M2 (M2-PK) for colorectal cancer screening: Prospective multicenter study. Am. J. Gastroenterol. 2008, 103, 1496-1504. [CrossRef] [PubMed]

76. Tonus, C.; Sellinger, M.; Koss, K.; Neupert, G. Faecal pyruvate kinase isoenzyme type M2 for colorectal cancer screening: A meta-analysis. World J. Gastroenterol. 2012, 18, 4004-4011. [CrossRef]

77. Uppara, M.; Adaba, F.; Askari, A.; Clark, S.; Hanna, G.; Athanasiou, T.; Faiz, O. A systematic review and meta-analysis of the diagnostic accuracy of pyruvate kinase M2 isoenzymatic assay in diagnosing colorectal cancer. World J. Surg. Oncol. 2015, 13, 48. [CrossRef]

78. Li, R.; Liu, J.; Xue, H.; Huang, G. Diagnostic value of fecal tumor M2-pyruvate kinase for CRC screening: A systematic review and meta-analysis. Int. J. Cancer 2012, 131, 1837-1845. [CrossRef] 
79. Keenan, J.; Aitchison, A.; Leaman, J.; Pearson, J.; Frizelle, F. Faecal biomarkers do not always identify pre-cancerous lesions in patients who present in primary care with bowel symptoms. N. Z. Med. J. 2019, 132, 48-56.

80. Rihan, M.; Nalla, L.V.; Dharavath, A.; Shard, A.; Kalia, K.; Khairnar, A. Pyruvate Kinase M2: A Metabolic Bug in Re-Wiring the Tumor Microenvironment. Cancer Microenviron. 2019, 12, 149-167. [CrossRef]

81. Zahra, K.; Dey, T.; Ashish; Mishra, S.P.; Pandey, U. Pyruvate Kinase M2 and Cancer: The Role of PKM2 in Promoting Tumorigenesis. Front. Oncol. 2020, 10, 159. [CrossRef]

82. Di Lena, M.; Porcelli, F.; Altomare, D.F. Volatile organic compounds as new biomarkers for colorectal cancer: A review. Colorectal Dis. 2016, 18, 654-663. [CrossRef]

83. Sonoda, H.; Kohnoe, S.; Yamazato, T.; Satoh, Y.; Morizono, G.; Shikata, K.; Morita, M.; Watanabe, A.; Morita, M.; Kakeji, Y.; et al. Colorectal cancer screening with odour material by canine scent detection. Gut 2011, 60, 814-819. [CrossRef] [PubMed]

84. Westenbrink, E.; Arasaradnam, R.P.; O'Connell, N.; Bailey, C.; Nwokolo, C.; Bardhan, K.D.; Covington, J.A. Development and application of a new electronic nose instrument for the detection of colorectal cancer. Biosens. Bioelectron. 2015, 67, 733-738. [CrossRef] [PubMed]

85. Arasaradnam, R.P.; McFarlane, M.J.; Ryan-Fisher, C.; Westenbrink, E.; Hodges, P.; Thomas, M.G.; Chambers, S.; O'Connell, N.; Bailey, C.; Harmston, C.; et al. Detection of colorectal cancer (CRC) by urinary volatile organic compound analysis. PLoS ONE 2014, 9, e108750. [CrossRef] [PubMed]

86. Amal, H.; Leja, M.; Funka, K.; Lasina, I.; Skapars, R.; Sivins, A.; Ancans, G.; Kikuste, I.; Vanags, A.; Tolmanis, I.; et al. Breath testing as potential colorectal cancer screening tool. Int. J. Cancer 2016, 138, 229-236. [CrossRef]

87. Wang, C.; Ke, C.; Wang, X.; Chi, C.; Guo, L.; Luo, S.; Guo, Z.; Xu, G.; Zhang, F.; Li, E. Noninvasive detection of colorectal cancer by analysis of exhaled breath. Anal. Bioanal. Chem. 2014, 406, 4757-4763. [CrossRef]

88. Altomare, D.F.; Di Lena, M.; Porcelli, F.; Trizio, L.; Travaglio, E.; Tutino, M.; Dragonieri, S.; Memeo, V.; de Gennaro, G. Exhaled volatile organic compounds identify patients with colorectal cancer. Br. J. Surg. 2013, 100, 144-150. [CrossRef]

89. van Keulen, K.E.; Jansen, M.E.; Schrauwen, R.W.M.; Kolkman, J.J.; Siersema, P.D. Volatile organic compounds in breath can serve as a non-invasive diagnostic biomarker for the detection of advanced adenomas and colorectal cancer. Aliment. Pharmacol. Ther. 2020, 51, 334-346. [CrossRef]

90. Wang, C.; Li, P.; Lian, A.; Sun, B.; Wang, X.; Guo, L.; Chi, C.; Liu, S.; Zhao, W.; Luo, S.; et al. Blood volatile compounds as biomarkers for colorectal cancer. Cancer Biol. Ther. 2014, 15, 200-206. [CrossRef]

91. de Meij, T.G.; Larbi, I.B.; van der Schee, M.P.; Lentferink, Y.E.; Paff, T.; Terhaar Sive Droste, J.S.; Mulder, C.J.; van Bodegraven, A.A.; de Boer, N.K. Electronic nose can discriminate colorectal carcinoma and advanced adenomas by fecal volatile biomarker analysis: Proof of principle study. Int. J. Cancer 2014, 134, 1132-1138. [CrossRef]

92. Batty, C.A.; Cauchi, M.; Lourenco, C.; Hunter, J.O.; Turner, C. Use of the Analysis of the Volatile Faecal Metabolome in Screening for Colorectal Cancer. PLoS ONE 2015, 10, e0130301. [CrossRef]

93. Bond, A.; Greenwood, R.; Lewis, S.; Corfe, B.; Sarkar, S.; O’Toole, P.; Rooney, P.; Burkitt, M.; Hold, G.; Probert, C. Volatile organic compounds emitted from faeces as a biomarker for colorectal cancer. Aliment. Pharmacol. Ther. 2019, 49, 1005-1012. [CrossRef] [PubMed]

94. Ishibe, A.; Ota, M.; Takeshita, A.; Tsuboi, H.; Kizuka, S.; Oka, H.; Suwa, Y.; Suzuki, S.; Nakagawa, K.; Suwa, H.; et al. Detection of gas components as a novel diagnostic method for colorectal cancer. Ann. Gastroenterol. Surg. 2018, 2, 147-153. [CrossRef]

95. Monedeiro, F.; Monedeiro-Milanowski, M.; Ligor, T.; Buszewski, B. A Review of GC-Based Analysis of Non-Invasive Biomarkers of Colorectal Cancer and Related Pathways. J. Clin. Med. 2020, 9, 3191. [CrossRef] [PubMed]

96. Erben, V.; Bhardwaj, M.; Schrotz-King, P.; Brenner, H. Metabolomics Biomarkers for Detection of Colorectal Neoplasms: A Systematic Review. Cancers 2018, 10, 246. [CrossRef] [PubMed]

97. Davis, S.C.; Yadav, J.S.; Barrow, S.D.; Robertson, B.K. Gut microbiome diversity influenced more by the Westernized dietary regime than the body mass index as assessed using effect size statistic. Microbiologyopen 2017, 6, e00476. [CrossRef]

98. Mima, K.; Ogino, S.; Nakagawa, S.; Sawayama, H.; Kinoshita, K.; Krashima, R.; Ishimoto, T.; Imai, K.; Iwasuki, M.; Hashimoto, D.; et al. The role of intestinal bacteria in the development and progression of gastrointestinal tract neoplasms. Surg. Oncol. 2017, 26, 368-376. [CrossRef]

99. Farshidfar, F.; Kopciuk, K.A.; Hilsden, R.; McGregor, S.E.; Mazurak, V.C.; Buie, W.D.; MacLean, A.; Vogel, H.J.; Bathe, O.F. A quantitative multimodal metabolomic assay for colorectal cancer. BMC Cancer 2018, 18, 26. [CrossRef]

100. Deng, L.; Ismond, K.; Liu, Z.; Constable, J.; Wang, H.; Alatise, O.I.; Weiser, M.R.; Kingham, T.P.; Chang, D. Urinary Metabolomics to Identify a Unique Biomarker Panel for Detecting Colorectal Cancer: A Multicenter Study. Cancer Epidemiol. Biomark. Prev. 2019, 28, 1283-1291. [CrossRef]

101. Imperiale, T.F. Noninvasive screening tests for colorectal cancer. Dig. Dis. 2012, 30, 16-26. [CrossRef]

102. Luo, Y.; Wong, C.J.; Kaz, A.M.; Dzieciatkowski, S.; Carter, K.T.; Morris, S.M.; Wang, J.; Willis, J.E.; Makar, K.M.; Ulrich, C.M.; et al. Differences in DNA methylation signatures reveal multiple pathways of progression from adenoma to colorectal cancer. Gastroenterology 2014, 147, 418-429.e8. [CrossRef]

103. Imperiale, T.F.; Ransohoff, D.F.; Itzkowitz, S.H.; Levin, T.R.; Lavin, P.; Lidgard, G.P.; Ahlquist, D.A.; Berger, B.M. Multitarget stool DNA testing for colorectal-cancer screening. N. Engl. J. Med. 2014, 370, 1287-1297. [CrossRef] [PubMed]

104. Warren, J.D.; Xiong, W.; Bunker, A.M.; Vaughn, C.P.; Furtado, L.V.; Roberts, W.L.; Fang, J.C.; Samowitz, W.S.; Heichman, K.A. Septin 9 methylated DNA is a sensitive and specific blood test for colorectal cancer. BMC Med. 2011, 9, 133. [CrossRef] [PubMed] 
105. Okugawa, Y.; Grady, W.M.; Goel, A. Epigenetic Alterations in Colorectal Cancer: Emerging Biomarkers. Gastroenterology 2015, 149, 1204-1225.e12. [CrossRef] [PubMed]

106. Zhao, Y.; Wang, C.; Goel, A. Role of gut microbiota in epigenetic regulation of colorectal Cancer. Biochim. Biophys. Acta Rev. Cancer 2021, 1875, 188490. [CrossRef] [PubMed]

107. Devall, M.; Sun, X.; Yuan, F.; Cooper, G.S.; Willis, J.; Weisenberger, D.J.; Casey, G.; Li, L. Racial Disparities in Epigenetic Aging of the Right vs Left Colon. J. Natl. Cancer Inst. 2020, 113, 1779-1782. [CrossRef]

108. Wang, W.; Kandimalla, R.; Huang, H.; Zhu, L.; Li, Y.; Gao, F.; Goel, A.; Wang, X. Molecular subtyping of colorectal cancer: Recent progress, new challenges and emerging opportunities. Semin. Cancer Biol. 2019, 55, 37-52. [CrossRef]

109. Shigeyasu, K.; Toden, S.; Zumwalt, T.J.; Okugawa, Y.; Goel, A. Emerging Role of MicroRNAs as Liquid Biopsy Biomarkers in Gastrointestinal Cancers. Clin. Cancer Res. 2017, 23, 2391-2399. [CrossRef]

110. Niki, M.; Nakajima, K.; Ishikawa, D.; Nishida, J.; Ishifune, C.; Tsukumo, S.I.; Shimada, M.; Nagahiro, S.; Mitamura, Y.; Yasutomo, K MicroRNA-449a deficiency promotes colon carcinogenesis. Sci. Rep. 2017, 7, 10696. [CrossRef]

111. Herring, E.; Tremblay, E.; McFadden, N.; Kanaoka, S.; Beaulieu, J.F. Multitarget Stool mRNA Test for Detecting Colorectal Cancer Lesions Including Advanced Adenomas. Cancers 2021, 13, 1228. [CrossRef]

112. Sears, C.L. Enterotoxigenic Bacteroides fragilis: A rogue among symbiotes. Clin. Microbiol. Rev. 2009, 22, 349-369. [CrossRef]

113. Rhee, K.J.; Wu, S.; Wu, X.; Huso, D.L.; Karim, B.; Franco, A.A.; Rabizadeh, S.; Golub, J.E.; Mathews, L.E.; Shin, J.; et al. Induction of persistent colitis by a human commensal, enterotoxigenic Bacteroides fragilis, in wild-type C57BL/6 mice. Infect. Immun. 2009, 77, 1708-1718. [CrossRef] [PubMed]

114. Purcell, R.V.; Pearson, J.; Aitchison, A.; Dixon, L.; Frizelle, F.A.; Keenan, J.I. Colonization with enterotoxigenic Bacteroides fragilis is associated with early-stage colorectal neoplasia. PLoS ONE 2017, 12, e0171602. [CrossRef] [PubMed]

115. Keenan, J.I.; Aitchison, A.; Purcell, R.V.; Greenlees, R.; Pearson, J.F.; Frizelle, F.A. Screening for enterotoxigenic Bacteroides fragilis in stool samples. Anaerobe 2016, 40,50-53. [CrossRef]

116. Toprak, N.U.; Yagci, A.; Gulluoglu, B.M.; Akin, M.L.; Demirkalem, P.; Celenk, T.; Soyletir, G. A possible role of Bacteroides fragilis enterotoxin in the aetiology of colorectal cancer. Clin. Microbiol. Infect. 2006, 12, 782-786. [CrossRef]

117. Tjalsma, H.; Boleij, A.; Marchesi, J.R.; Dutilh, B.E. A bacterial driver-passenger model for colorectal cancer: Beyond the usual suspects. Nat. Rev. Microbiol. 2012, 10, 575-582. [CrossRef]

118. Shen, X.J.; Rawls, J.F.; Randall, T.; Burcal, L.; Mpande, C.N.; Jenkins, N.; Jovov, B.; Abdo, Z.; Sandler, R.S.; Keku, T.O. Molecular characterization of mucosal adherent bacteria and associations with colorectal adenomas. Gut Microbes 2010, 1, 138-147. [CrossRef]

119. Hale, V.L.; Chen, J.; Johnson, S.; Harrington, S.C.; Yab, T.C.; Smyrk, T.C.; Nelson, H.; Boardman, L.A.; Druliner, B.R.; Levin, T.R.; et al. Shifts in the Fecal Microbiota Associated with Adenomatous Polyps. Cancer Epidemiol. Biomark. Prev. 2017, 26, 85-94. [CrossRef]

120. Feng, Q.; Liang, S.; Jia, H.; Stadlmayr, A.; Tang, L.; Lan, Z.; Zhang, D.; Xia, H.; Xu, X.; Jie, Z.; et al. Gut microbiome development along the colorectal adenoma-carcinoma sequence. Nat. Commun. 2015, 6, 6528. [CrossRef]

121. Nakatsu, G.; Li, X.; Zhou, H.; Sheng, J.; Wong, S.H.; Wu, W.K.; Ng, S.C.; Tsoi, H.; Dong, Y.; Zhang, N.; et al. Gut mucosal microbiome across stages of colorectal carcinogenesis. Nat. Commun. 2015, 6, 8727. [CrossRef]

122. Sobhani, I.; Tap, J.; Roudot-Thoraval, F.; Roperch, J.P.; Letulle, S.; Langella, P.; Corthier, G.; Tran Van Nhieu, J.; Furet, J.P. Microbial dysbiosis in colorectal cancer (CRC) patients. PLOS ONE 2011, 6, e16393. [CrossRef]

123. Wang, T.; Cai, G.; Qiu, Y.; Fei, N.; Zhang, M.; Pang, X.; Jia, W.; Cai, S.; Zhao, L. Structural segregation of gut microbiota between colorectal cancer patients and healthy volunteers. ISME J. 2012, 6, 320-329. [CrossRef] [PubMed]

124. Kostic, A.D.; Chun, E.; Robertson, L.; Glickman, J.N.; Gallini, C.A.; Michaud, M.; Clancy, T.E.; Chung, D.C.; Lochhead, P.; Hold, G.L.; et al. Fusobacterium nucleatum potentiates intestinal tumorigenesis and modulates the tumor-immune microenvironment. Cell Host Microbe 2013, 14, 207-215. [CrossRef] [PubMed]

125. Flanagan, L.; Schmid, J.; Ebert, M.; Soucek, P.; Kunicka, T.; Liska, V.; Bruha, J.; Neary, P.; Dezeeuw, N.; Tommasino, M.; et al Fusobacterium nucleatum associates with stages of colorectal neoplasia development, colorectal cancer and disease outcome. Eur. J. Clin. Microbiol. Infect. Dis 2014, 33, 1381-1390. [CrossRef] [PubMed]

126. Liang, Q.; Chiu, J.; Chen, Y.; Huang, Y.; Higashimori, A.; Fang, J.; Brim, H.; Ashktorab, H.; Ng, S.C.; Ng, S.S.M.; et al. Fecal Bacteria Act as Novel Biomarkers for Noninvasive Diagnosis of Colorectal Cancer. Clin. Cancer Res. 2017, 23, 2061-2070. [CrossRef]

127. Wong, S.H.; Kwong, T.N.Y.; Chow, T.C.; Luk, A.K.C.; Dai, R.Z.W.; Nakatsu, G.; Lam, T.Y.T.; Zhang, L.; Wu, J.C.Y.; Chan, F.K.L.; et al. Quantitation of faecal Fusobacterium improves faecal immunochemical test in detecting advanced colorectal neoplasia. Gut 2017, 66, 1441-1448. [CrossRef]

128. Viljoen, K.S.; Dakshinamurthy, A.; Goldberg, P.; Blackburn, J.M. Quantitative profiling of colorectal cancer-associated bacteria reveals associations between fusobacterium spp., enterotoxigenic Bacteroides fragilis (ETBF) and clinicopathological features of colorectal cancer. PLoS ONE 2015, 10, e0119462. [CrossRef]

129. Hamada, T.; Zhang, X.; Mima, K.; Bullman, S.; Sukawa, Y.; Nowak, J.A.; Kosumi, K.; Masugi, Y.; Twombly, T.S.; Cao, Y.; et al. Fusobacterium nucleatum in Colorectal Cancer Relates to Immune Response Differentially by Tumor Microsatellite Instability Status. Cancer Immunol. Res. 2018, 6, 1327-1336. [CrossRef]

130. Brennan, C.A.; Clay, S.L.; Lavoie, S.L.; Bae, S.; Lang, J.K.; Fonseca-Pereira, D.; Rosinski, K.G.; Ou, N.; Glickman, J.N.; Garrett, W.S Fusobacterium nucleatum drives a pro-inflammatory intestinal microenvironment through metabolite receptor-dependent modulation of IL-17 expression. Gut Microbes 2021, 13, 1987780. [CrossRef] 
131. Hale, V.L.; Jeraldo, P.; Chen, J.; Mundy, M.; Yao, J.; Priya, S.; Keeney, G.; Lyke, K.; Ridlon, J.; White, B.A.; et al. Distinct microbes, metabolites, and ecologies define the microbiome in deficient and proficient mismatch repair colorectal cancers. Genome Med. 2018, 10, 78. [CrossRef]

132. Wu, G.D.; Chen, J.; Hoffmann, C.; Bittinger, K.; Chen, Y.Y.; Keilbaugh, S.A.; Bewtra, M.; Knights, D.; Walters, W.A.; Knight, R.; et al. Linking long-term dietary patterns with gut microbial enterotypes. Science 2011, 334, 105-108. [CrossRef]

133. Zackular, J.P.; Baxter, N.T.; Chen, G.Y.; Schloss, P.D. Manipulation of the Gut Microbiota Reveals Role in Colon Tumorigenesis. mSphere 2016, 1, e00001-15. [CrossRef] [PubMed]

134. Butto, L.F.; Haller, D. Dysbiosis in intestinal inflammation: Cause or consequence. Int. J. Med. Microbiol. 2016, 306, 302-309. [CrossRef] [PubMed]

135. Yuan, C.; Steer, C.J.; Subramanian, S. Host(-)MicroRNA(-)Microbiota Interactions in Colorectal Cancer. Genes 2019, 10, 270. [CrossRef] [PubMed]

136. Pereira, F.C.; Berry, D. Microbial nutrient niches in the gut. Environ. Microbiol. 2017, 19, 1366-1378. [CrossRef]

137. Cruz, A.; Carvalho, C.M.; Cunha, A.; Crespo, A.; Iglesias, A.; Garcia-Nimo, L.; Freitas, P.P.; Cubiella, J. Faecal Diagnostic Biomarkers for Colorectal Cancer. Cancers 2021, 13, 5568. [CrossRef]

138. Baxter, N.T.; Ruffin, M.T.t.; Rogers, M.A.; Schloss, P.D. Microbiota-based model improves the sensitivity of fecal immunochemical test for detecting colonic lesions. Genome Med. 2016, 8, 37. [CrossRef]

139. Scully, S.; Yan, W.; Bentley, B.; Cao, Q.J.; Shao, R. Inhibitory activity of YKL-40 in mammary epithelial cell differentiation and polarization induced by lactogenic hormones: A role in mammary tissue involution. PLoS ONE 2011, 6, e25819. [CrossRef]

140. Miro-Blanch, J.; Yanes, O. Epigenetic Regulation at the Interplay Between Gut Microbiota and Host Metabolism. Front. Genet. 2019, 10, 638. [CrossRef]

141. Yuan, C.; Burns, M.B.; Subramanian, S.; Blekhman, R. Interaction between Host MicroRNAs and the Gut Microbiota in Colorectal Cancer. mSystems 2018, 3, e00205-17. [CrossRef] 